\title{
PENGARUH PENERAPAN MODEL PEMBELAJARAN PROBLEM BASED LEARNING TERHADAP PENINGKATAN KETERAMPILAN BERPIKIR KRITIS DAN PEMAHAMAN KONSEP SISWA
}

\section{Raudatul Jannah', Alwan Mahsul', Syarifatul Mubarak'}

${ }^{1}$ Tadris Kimia, FTK UIN Mataram, Mataram.

Email: syarif.almubarak@uinmataram.ac.id

²Tadris IPA Biologi, FTK UIN Mataram, Mataram

\section{ABSTRAK}

Penelitian ini bertujuan untuk mengetahui pengaruh penerapan model pembelajaran problem based learning terhadap peningkatan keterampilan berpikir kritis dan pemahaman konsep siswa pada materi larutan penyangga. Metode pelaksanaannya menggunakan desain pretest and posttest control group design yaitu penelitian yang melihat perbedaan hasil pretest dan hasil posttest antara kelas eksperimen dan kelas kontrol. Populasi penelitian ini adalah kelas XI IPA. Berdasarkan uji kesamaan ratarata yang telah dilakukan, menunjukkan semua anggota populasi memiliki kemampuan awal yang sama. Teknik pengambilan sampel yang digunakan dalam penelitian ini adalah simple Random Sampling. Pengambilan sampel dengan teknik simple random sampling sehingga didapat XI IPA 2 sebagai kelas eksperimen dan XI IPA 1 sebagai kelas kontrol. Analisa uji perbedaan rata-rata hasil posttest kelas eksperimen menunjukan hasil yang lebih baik dibandingkan kelas kontrol. Kelas eksperimen memperoleh ratarata nilai posttest 72,08 sedangkan nilai kelas kontrol 65,48. Uji NGain pada hasil belajar kognitif siswa menunjukan bahwa kelas eksperimen mengalami peningkatan lebih baik dalam keterampilan berpikir kritis dan pemahaman konsep sebesar 63,2976 dan kelas kontrol peningkatannya sebesar 56,50 dengan kriteria sedang. Bedasarkan hasil analisis tersebut disimpulkan bahwa terdapat pengaruh penerapan model pembelajaran problem based learning 
terhadap peningkatan keterampilan berpikir kritis dan pemahaman konsep siswa pada materi larutan penyangga.

Kata kunci: keterampilan berpikir kritis, larutan penyangga, pemahaman konsep, problem based learning.

\section{PENDAHULUAN}

Era globalisasi memberi dampak yang cukup luas dalam berbagai aspek kehidupan, termasuk tuntutan dalam penyelenggaraan pendidikan. Salah satu tantangan nyata tersebut bahwa pendidikan hendaknya mampu menghasilkan sumber daya manusia yang memiliki kompetensi utuh dan dikenal dengan kompetensi abad ke-21. Kompetensi abad ke-21 merupakan kompetensi utama yang harus dimiliki siswa agar mampu berkiprah dalam kehidupan nyata pada abad ke-21 (Wijaya, 2016).

Era yang semakin hebat menimbulkan persaingan dalam berbagai bidang kehidupan, diantaranya bidang pendidikan khususnya pendidikan sains. Solusi untuk menghadapinya dibutuhkan sumber daya manusia yang berkualitas, salah satu cara yang digunakan adalah melalui peningkatan mutu pendidikan. Penyediaan sumber daya manusia yang mampu berpikir kritis merupakan salah satu agenda penting dan isu vital dalam pendidikan modern (Widowati, 2009).

Berpikir kritis adalah berpikir rasional tentang sesuatu. Kemudian mengumpulkan informasi sebanyak mungkin tentang sesuatu tersebut sebelum mengambil suatu keputusan atau melakukan suatu tindakan. Seseorang yang mempunyai keterampilan berpikir kritis dapat diidentifikasi dari perilaku yang diperlihatkannya. Lima perilaku tersebut adalah sebagai berikut (Haryani, 2012). (1) Keterampilan menganalisis merupakan suatu keterampilan menguraikan sebuah struktur ke dalam komponenkomponen agar mengetahui pengorganisasian struktur tersebut. Keterampilan ini terkandung tujuan untuk memahami sebuah konsep dengan cara menguraikan atau merinci globalitas tersebut ke dalam bagian-bagian yang lebih kecil dan terperinci. 
Keterampilan mensintesis merupakan keterampilan yang berlawanan dengan keterampilan menganalisis. Keterampilan mensintesis adalah keterampilan menggabungkan bagian-bagian menjadi sebuah bentukan atau susunan yang baru. (3) Keterampilan Mengenal dan Memecahkan Masalah Keterampilan ini merupakan katerampilan aplikatif konsep kepada beberapa pengertian. Keterampilan ini menuntut pembaca untuk memahami bacaan dengan kritis sehingga setelah selesai kegiatan membaca mampu menangkap beberapa pokok pikiran bacaan, sehingga mampu mempola sebuah konsep. (4) Keterampilan menyimpulkan adalah kegiatan akal pikiran manusia berdasarkan pengertian/ pengetahuan (kebenaran) yang dimilikinya, dapat beranjak mencapai pengertian (kebenaran) yang baru yang lain. (5) Keterampilan Mengevaluasi atau Menilai Keterampilan ini menuntut pemikiran yang matang dalam menentukan nilai sesuatu dengan berbagai kriteria yang ada.

Alasan yang dapat dijadikan kurangnya kualitas pendidikan di Indonesia adalah lemahnya proses pembelajaran. Siswa dipaksa untuk mengingat dan menimbun berbagai informasi tanpa dibimbing memahami informasi yang diingatnya itu. Akibatnya ketika siswa lulus dari sekolah, mereka pintar secara teori tetapi mereka miskin aplikasi. Pendidikan di Sekolah terlalu menekan otak mereka untuk menghafal bahan ajar. Fungsi dari pendidikan adalah untuk membantu siswa dalam mengkonstruksi pengetahuan sendiri tentang dunia dibandingkan hanya pasif menerima informasi (Wulandari, 2011).

Facione \& Facione (2008) menyatakan bahwa berpikir kritis sebagai pengaturan diri dalam memutuskan sesuatu yang menghasilkan interpretasi, analisis, evaluasi, dan inferensi, maupun pemaparan menggunakan suatu bukti, konsep, metodologi, kriteria, atau pertimbangan kontekstual yang menjadi dasar dibuatnya keputusan. Berpikir kritis merupakan suatu kekuatan serta sumber tenaga dalam kehidupan bermasyarakat dan personal seseorang. 
Berpikir kritis sebagai proses disiplin cerdas dari konseptualisasi, penerapan, analisis, sintesis, dan evaluasi aktif dan berketerampilan yang dikumpulkan dari, atau dihasilkan oleh, observasi, pengalaman, refleksi, penalaran, atau komunikasi sebagai sebuah penuntun menuju kepercayaan dan aksi. Selain itu, berpikir kritis juga telah didefinisikan sebagai berpikir yang memiliki maksud, masuk akal, dan berorientasi tujuan serta kecakapan untuk menganalisis sesuatu informasi dan ide-ide secara hati-hati dan logis dari berbagai macam perspektif (Zubaidah, 2010).

Pada umumnya pembelajaran di sekolah masih terpaku pada kurikulum atau terstruktur. Hal tersebut dapat menyebabkan minimnya pengetahuan baru serta rendahnya kemampuan memecahkan masalah. Padahal selain dilakukan di dalam kelas dan Laboratorium, pembelajaran kimia sebenarnya dapat dilakukan dengan mempelajari fenomena yang ada di lingkungan sekitar sehingga siswa tertantang dan dapat berperan aktif dalam menyelesaikan masalah-masalah yang diberikan oleh guru berkaitan dengan konsep-konsep kimia.

Bedasarkan hasil observasi yang telah dilakukan oleh peneliti pada tanggal 3 November 2019 di kelas XI IPA SMAN 2 Jonggat diperoleh hasil bahwa sebagian besar siswa hanya mencatat dan mendengarkan penjelasan yang disampaikan oleh guru, sehingga siswa kurang tertarik pada pembelajaran kimia yang disampaikan dan cenderung malas untuk belajar. Hal ini menyebabkan kurangnya keterampilan berpikir kritis siswa karena pemahaman konsep yang kurang didukung pula dengan pembelajaran masih menggunakan metode konvensional. Metode yang paling sering digunakan oleh guru adalah metode ceramah dan metode diskusi, namun metode diskusi hanya digunakan pada materi tertentu karena jika terlalu sering menggunakan metode diskusi akan membutuhkan banyak waktu.

Salah satu model pembelajaran yang dapat mengatasi permasalahan tersebut adalah penerapan model problem based learning (PBL). PBL merupakan model pembelajaran yang memberikan tantangan kepada siswa untuk menemukan 
Jannah, R., Mahsul, A., \& Mubarak, S. (2020)

Doi: 10.20414/spin.v2i2.2697

pemecahan masalah nyata atau open-ended secara individu atau kelompok. PBL mendorong siswa untuk mengembangkan kemampuannya sebagai pembelajar. Permasalahan yang dihadapkan kepada siswa diseleksi dengan tujuan untuk menimbulkan rasa keingintahuan siswa dengan cara menghubungkannya dengan kehidupan sehari-hari sehingga mendorong siswa untuk berpikir kritis dan analisis (widowati, 2009).

PBL adalah suatu pendekatan pembelajaran yang mengguanakan maslah dunia nyata sebagai suatu konteks bagi peserta didik untuk belajar tentang cara berpikir kritis dan keterampilan pemecahan masalah, serta untuk memperoleh pengetahuan dan konsep yang esensial dari pelajaran. Landasan teori PBL adalah kolaborativisme, suatu pandangan yang berpendapat bahwa siswa akan Menyusun pengetahuan dengan cara membangun penalaran dari semua pengetahuan yang sudah dimlikinya sebagai hasil kegiatan berinteraksi dengan sesama indivi du (Lidinillah, 2014). Hal tersebut juga menyiratkan bahwa proses pembelajaran berpindah dari transfer informasi. Menurut paham kosntruktivisme, manusia hanya dapat memahami melalui segala sesuatu yang dikonstruksinya sendiri.

\section{METODE}

Jenis penelitian yang digunakan adalah penelitian kuantitatif dengan pendekatan quasi eksperimen, yakni suatu bentuk rancangan penelitian yang mempunyai kelompok kontrol dan kelompok eksperimen. Pelaksanaan penelitian ini menggunakan jenis desain penelitian dengan metode pretest-posttest control group design dapat dirumuskan sebagai berikut:

Tabel 1. Desain penelitian

$\begin{array}{llll}\text { Eksperimen } & \mathrm{O}_{1} & \mathrm{X} & \mathrm{O}_{2}\end{array}$

Kontrol $\quad \mathrm{O}_{3}-\mathrm{O}_{4}$


Keterangan :

$\mathrm{O}_{1}=$ Pemberian tes awal pada kelas eksperimen sebelum diberikan perlakuan.

$\mathrm{O}_{2}=$ Pemberian tes akhir pada kelas eksperimen setelah diberikan perlakuan.

$\mathrm{O}_{3}=$ Pemberian tes awal pada kelas kontrol sebelum diberikan perlakuan.

$\mathrm{O}_{4}=$ Pemberian tes akhir pada kelas kontrol setelah diberikan perlakuan.

$\mathrm{X}=$ Perlakuan berupa model problem based learning

- = Perlakuan berupa pembelajaran konvensional.

Terdapat dua kelompok yang dipilih secara simpel random sampling sebelum diberi pretest untuk mengetahui keadaan awal antara kelompok eksperimen dan kelompok control (Sugiyono, 2009). Setelah diketahui hasil dari pretest dari kelas eksperimen dan kelas kontrol, maka pada kelas eksperimen diberikan perlakuan (X), sedangkan pada kelas kontrol tidak diberikan perlakuan (-). Setelah diberikan perlakuan atau treatment pada salah satu kelompok sampel (kelompok eksperimen) dilanjutkan dengan pemberian posttest pada kelompok eksperimen dan kelompok kontrol yang digunakan.

Populasi dalam penelitian ini adalah seluruh siswa kelas XI IPA SMAN 2 Jonggat yang terdiri dari tiga kelas. Dari populasi ini dipilih sampel secara simple random sampling yaitu teknik pengambilan sampel dari anggota populasi yang dilakukan secara acak tanpa memperhatikan strata yang ada dalam populasi. Pengambilan sampel dilakukan secara acak sehingga akan didapatkan 2 kelas penelitian (kelas eksperimen dan kelas kontrol). Sampel dipilih 2 kelas yaitu kelas XI IPA 2 sebagai kelas eksperimen yang terdiri dari 20 siswa diajarkan dengan model PBL dan kelas XI IPA 1 sebagai kelas kontrol tediri dari 21 siswa diajarkan dengan metode konvensional.

Instrumen yang digunakan dalam penelitian ini yaitu Silabus, RPP, LKS, Angket tanggapan siswa, Tes keterampilan berpikir kritis 
dan pemahaman konsep. Tes ini menggunakan teknik tes tertulis dengan bentuk tes tow tier multiple choice yang mengacu pada kemampuan kognitif siswa $\left(C_{4}, C_{5}, C_{6}\right)$.

Pengumpulan data merupakan prosedur dan standar untuk memperoleh data yang diperlukan. Teknik pengumpulan data yang akan digunakan dalam penelitian ini adalah metode tes dalam bentuk soal pilihan ganda 12 soal. Data penelitian ini diperoleh dari data hasil tes akhir (posttest) setelah diberikan perlakuan.

1. Uji Prasyarat Analisis

Uji prasyarat analisis merupakan syarat yang harus dipenuhi sebelum melakukan uji hipotesis. Data yang telah diperoleh melalui tes akhir (posttest) pada kelas eksperimen maupun kelas kontrol akan diuji normalitas dan homogenitas data untuk menentukan uji hipotesis yang akan digunakan

2. Penentuan Gain

Setelah diperoleh skor pretest dan posttest, selanjutnya dihitung selisih antara pretest dan posttest. Rumus yang digunakan untuk memperoleh skor Gain, yaitu: $\mathrm{G}=\mathrm{T}_{2}-\mathrm{T}_{1}$

3. Uji Hipotesis

Uji hipotesis penelitian didasarkan pada data nilai pretest dan data Normalized Gain (N-Gain). Menurut Sugiyono untuk sampel independen (tidak berkorelasi) mempunyai ketentuan, jika kedua data berdistribusi normal dan variansnya homogen maka dilanjutkan dengan uji $t$ (test). Adapun langkah-langkah uji-t sebagai berikut:

a. Membuat Ha dan Ho dalam bentuk kalimat

b. Membuat Ha dan Ho model statistik

c. Mencari rata-rata (x), standar deviasi (s), varians $\left(\mathrm{s}_{2}\right)$ dan korelasi

d. Mencari nilai t dengan rumus:

$t=\frac{x 1-x 2}{\sqrt{\frac{s 12}{n 1}-\frac{s 22}{n 2}}}$ 
Keterangan:

$\mathrm{t}=$ nilai $\mathrm{t}$ hitung

$\mathrm{x}_{1}=$ nilai rata-rata kelas eksperimen

$\mathrm{x}_{2}=$ nilai rata-rata kelas kontrol

$s_{1}^{2}=$ varian kelas eksperimen

$s_{2}^{2}=$ varian kelas kontrol

$\mathrm{n}_{1}=$ jumlah sampel kelas eksperimen

$\mathrm{n}_{2}=$ jumlah sampel kelas kontrol.

Pengujian ini dilakukan dengan uji t yang diolah menggunakan software SPSS versi 16.0 for windows dengan taraf signifika $5 \%$.

a. Jika nilai signifikansi $\geq 0,05$ maka Ha diterima

b. Jika nilai signifikansi $\leq 0,05$ maka Ho ditolak

\section{HASIL DAN PEMBAHASAN}

\section{a. Analisis data diskriptif awal Pretest dan Posttest}

Setelah dilakukan pengolahan data hasil pretest dan posttest kelas eksperimen dan kelas kontrol, diperoleh statistik deskriptif. Di bawah ini disajikan statistik deskriptif data hasil pretest kelas eksperimen dan kelas kontrol dengan menggunakan program SPSS 16.0 for Windows.

Table 2. Statistik deskriptif nilai pretest kelas eksperimen dan kelas kontrol

\begin{tabular}{llllllll}
\hline \multicolumn{7}{c}{ Descriptive Statistics } \\
\hline Kelas & N & Range & Min & Max & Mean & Std. Dev & Var \\
\hline Eksperimen & 20 & 25.00 & 16.00 & 41.00 & 25.150 & 7.414 & 54.976 \\
Kontrol & 21 & 41.00 & .00 & 41.00 & 15.524 & 10.122 & 102.462 \\
Valid N & & & & & & & \\
(listwise) & 20 & & & & & & \\
\hline
\end{tabular}


Tabel 3. Statistik diskriptif nilai posttest kelas eksperimen dan kelas kontrol

\begin{tabular}{llllllll}
\hline \multicolumn{7}{c}{ Descriptive Statistics } \\
\hline Kelas & N & Range & Min & Max & Mean & Std. Dev & Var \\
\hline Eksperimen & 20 & 75.00 & 25.00 & 100.00 & 71.850 & 20.797 & 432.555 \\
Kontrol & 21 & 84.00 & 16.00 & 100.00 & 62.762 & 29.770 & 886.290 \\
Valid N & & & & & & & \\
(listwise) & 20 & & & & & & \\
\hline
\end{tabular}

Berdasarkan tabel 2 dan tabel 3 terlihat bahwa terdapat perbedaan antara rata-rata hasil pretest dan posttest. Ratarata untuk hasil pretest untuk kelas eksperimen 25,15 dan untuk kelas kontrol 15,52. Dan untuk hasil posttest kelas eksperimen 71,85 dan untuk kelas kontrol 62,76. Dilihat dari nilai rata-rata kedua hasil terdapat perbedaan rata-rata untuk kedua hasil tersebut. Namun untuk memastikan apakah perbedaan tersebut cukup berarti atau tidak maka dilakukan uji statistik sebagai berikut.

\section{b. Uji Normalitas}

Setelah diketahui gambaran statistik deskriptif skor pretest dan Posttest dari kelas eksperimen dan kelas kontrol, langkah selanjutnya adalah melakukan uji normalitas terhadap skor pretest dan Posttest untuk kelas eksperimen dan kelas kontrol. Pengujian normalitas data tersebut akan dilakukan dengan menggunakan excel dengan uji chi kuadrat dengan $f_{o}$ menyatakan frekuensi yang diamati dan $f_{h}$ menyatakan frekuensi yang diharapkan. Untuk mengetahui apakah data terdistribusi normal atau tidak, nilai $\chi_{\text {hitung }}{ }^{2}$ dibandingkan dengan nilai $\chi_{\text {tabel }}^{2}$ pada taraf signifikan $5 \%$ dengan derajat kebebasan $\mathrm{db}=\mathrm{k}-1$, dimana $\mathrm{K}$ menyatakan jumlah kelas interval. Setelah dilakukan pengolahan data, tampilan outputnya dapat dilihat pada Tabel 2 dan tabel 3 . 
Table 4. Output data normalitas distribusi hasil pretest

\begin{tabular}{llll}
\hline \multirow{3}{*}{ Nilai pretest } & Kelas & $\mathrm{X}_{\text {hitung }}{ }^{2}$ & $\mathrm{X}_{\text {tabel }^{2}}$ \\
\cline { 2 - 4 } & Eksperimen & 0,04 & 7,81 \\
& Kontrol & 0,91 & 7,81 \\
\hline
\end{tabular}

Tabel 5. Output data normalitas distribusi hasil pretest dan posttest

\begin{tabular}{llll}
\hline \multirow{3}{*}{ Nilai posttest } & Kelas & $\mathrm{X}_{\text {hitung }}{ }^{2}$ & $\mathrm{X}_{\text {tabel }^{2}}$ \\
\cline { 2 - 4 } & Eksperimen & 3,09 & 7,81 \\
& Kontrol & 6,87 & 7,81 \\
\hline
\end{tabular}

Berdasarkan hasil perhitungan menggunakan uji chi kuadrat dari kelas eksperimen dan kelas kontrol $\mathrm{X}_{\text {hitung }}{ }^{2}$ kurang dari $X_{\text {tabel }}{ }^{2}$ dengan demikian dapat disimpulkan bahwa data sampel berasal dari populasi berdistribusi normal.

\section{c. Uji Homogenitas}

Setelah dilakukan uji normalitas dan diperoleh data berdistribusi normal, selanjutnya dilakukan uji homogenitas dua varians antara kelas eksperimen dan kelas kontrol dengan menggunakan uji levene melalui program SPSS 16.0 for windows. Taraf signifikasi 0,05 . Tampilan outputnya seperti terdapat pada table 6

Tabel 6. Output data homogenitas distribusi kelas eksperimen dan kelas kontrol

\begin{tabular}{cccc}
\hline \multicolumn{4}{c}{ Test of homogeneity of variances } \\
\hline hasil belajar kimia \\
\hline Levene Statistic & $\mathrm{df1}$ & $\mathrm{df2}$ & Sig. \\
3.728 & 1 & 39 & .061 \\
\hline
\end{tabular}

Berdasarkan hasil perhitungan diperoleh bahwa nilai signifikasi sebesar 0,061, Hipotesis yang diuji adalah Ho: Varian kedua kelompok sama H1: Varians kedua kelompok berbeda Kriteria penolakan Ho; tolak Ho jika p < alfa (0.05) Pada hasil ini, $\mathrm{p}>0.05$, artinya Ho diterima, dengan demikian kedua 
kelompok memiliki varians yang sama. Jadi dapat disimpulkan bahwa kelas eksperimen dan kelas kontrol berasal dari populasi-populasi yang mempunyai varians yang sama atau kedua kelas tersebut homogen.

\section{d. Uji Gain}

Setelah diperoleh skor pretest dan skor posttest, selanjutnya dihitung selisih antara skor pretest dan skor posttest. Setelah dilakukan pengolahan data, tampilan outputnya dapat dilihat pada Tabel 7 .

Tabel 7. Output data uji $\mathrm{N}$ - gain kelas eksperimen dan kelas kontrol

\begin{tabular}{lll}
\hline & \multicolumn{2}{l}{$\begin{array}{l}\text { Keterampilan berpikir } \\
\text { dan pemahitis }\end{array}$} \\
\cline { 2 - 3 } & Eksperimen & Kontrol \\
\cline { 2 - 3 } Indeks gain & 63,297 & 56,501 \\
Peningkatan & $63,30 \%$ & $56,50 \%$ \\
\hline
\end{tabular}

Berdasarkan hasil perhitungan uji $\mathrm{N}$-gain score, menujukkan bahwa nilai rata-rata $\mathrm{N}$-Gain score untuk kelas eksperimen (model pembelajaran PBL) sebesar 63,2976 atau 63,30\% termasuk dalam katagori cukup efektif, dengan nilai $\mathrm{N}$-Gain score minimal 20\% dan maksimal $70 \%$. Sementara untuk uji N-Gain score untuk kelas kontrol (metode konvesional) sebesar 56,50\% termasuk dalam katagori cukup efektif dengan nilai $\mathrm{N}$-Gain score minimal 20\% dan maksimal $70 \%$.

\section{e. Uji hipotesis}

Karena kedua sampel (kelas eksperimen dan kelas kontrol) berasal dari populasi yang berdistribusi normal dan memiliki varians yang homogen maka dilanjutkan dengan Uji-t yaitu dengan menggunakan rumus t-Test polled varians dengan taraf signifikansinya 0,05 sebagai berikut:

Ho: $\mu 1 \leq \mu 2$

Ha: $\mu 1>\mu 2$

Keterangan: 
Ho: Tidak ada pengaruh model pembelajaran problem based learning terhadap peningkatan keterampilan berpikir kritis dan pemahaman konsep siswa pada materi larutan penyangga SMA Negeri 2 Jonggat

Ha: Ada pengaruh model pembelajaran problem based learning terhadap peningkatan keterampilan berpikir kritis dan pemahaman konsep siswa pada materi larutan penyangga SMA Negeri 2 Jonggat

Hasil output Independen Sample t-test melalui program SPSS 16.0 for windows untuk uji kesamaan dua rata-rata dapat dilihat pada Tabel 8.

Tabel 8. Output data uji hipotesis kelas eksperimen dan kelas kontrol

\begin{tabular}{|c|c|c|c|c|c|c|c|c|c|}
\hline \multicolumn{10}{|c|}{ Independent Samples Test } \\
\hline & & $\begin{array}{l}\text { Levene's } \\
\text { Test for } \\
\text { Equality of } \\
\text { Variances }\end{array}$ & \multicolumn{7}{|c|}{ t-test for Equality of Means } \\
\hline & & \multirow[t]{2}{*}{ Sig. } & \multirow[t]{2}{*}{$\mathrm{T}$} & \multirow[t]{2}{*}{ Df } & \multirow[t]{2}{*}{$\begin{array}{l}\text { Sig. (2- } \\
\text { tailed) }\end{array}$} & \multirow[t]{2}{*}{$\begin{array}{l}\text { Mean } \\
\text { Differ } \\
\text { ence }\end{array}$} & \multirow{2}{*}{$\begin{array}{l}\text { Std. } \\
\text { Error } \\
\text { Differ } \\
\text { ence }\end{array}$} & $\begin{array}{l}95 \% \text { Con } \\
\text { Interval } \\
\text { Differen }\end{array}$ & $\begin{array}{l}\text { fidence } \\
\text { of the } \\
\text { ice }\end{array}$ \\
\hline & & & & & & & & Lower & Upper \\
\hline \multirow[b]{2}{*}{ Nilai } & $\begin{array}{l}\text { Equal } \\
\text { variances } \\
\text { assumed }\end{array}$ & 6.381 .016 & -1.128 & 39 & .266 & 9.088 & 8.058 & -25.388 & 7.211 \\
\hline & $\begin{array}{l}\text { Equal } \\
\text { variances } \\
\text { not } \\
\text { assumed }\end{array}$ & & -1.138 & $\begin{array}{l}35 . \\
842\end{array}$ & .263 & 9.088 & 7.989 & -25.294 & 7.117 \\
\hline
\end{tabular}


Tabel 9. Output data uji manova kelas eksperimen dan kelas kontrol

\begin{tabular}{|c|c|c|c|c|c|c|}
\hline \multicolumn{7}{|c|}{ Multivariate Tests ${ }^{b}$} \\
\hline \multicolumn{2}{|l|}{ Effect } & Value & $\mathrm{F}$ & $\begin{array}{l}\text { Hypothe } \\
\text { sis df }\end{array}$ & Error df & Sig. \\
\hline \multirow[t]{5}{*}{ Intercept } & Pillai's Trace & .932 & $1.229 \mathrm{E} 2^{\mathrm{a}}$ & 2.000 & 18.000 & .000 \\
\hline & $\begin{array}{l}\text { Wilks' } \\
\text { Lambda }\end{array}$ & .068 & $1.229 \mathrm{E}^{\mathrm{a}}$ & 2.000 & 18.000 & .000 \\
\hline & $\begin{array}{l}\text { Hotelling's } \\
\text { Trace }\end{array}$ & 13.659 & $1.229 \mathrm{E}^{\mathrm{a}}$ & 2.000 & 18.000 & .000 \\
\hline & Roy's & & & & & \\
\hline & $\begin{array}{l}\text { Largest } \\
\text { Root }\end{array}$ & 13.659 & $1.229 \mathrm{E}^{\mathrm{a}}$ & 2.000 & 18.000 & .000 \\
\hline
\end{tabular}

a. Exact statistic

b. Design: Intercept

Pemahaman konsep adalah suatu jenjang dalam ranah kognitif yang menunjukan kemampuan menjelaskan hubungan yang sederhana antara fakta-fakta dan konsep. Pemahaman konsep dapat dibentuk melalui pengalaman langsung dengan objek atau kejadian dalam kehidupan nyata.Pemahaman konsep pada materi larutan penyangga diartikan sebagai kemampuan mengungkapkan makna suatu konsep pada materi larutan penyangga yang meliputi kemampuan membedakan, menjelaskan, menguraikan lebih lanjut, dan mengubah konsep yang berisi gagasan atau ide mengenai suatu materi, pengalaman, peristiwa atau suatu objek yang didasarkan pada ciri-ciri yang dimiliki oleh objek itu sendiri.

Pada penelitian ini hasil pretest pada materi larutan penyangga yang ditunjukan dengan rata-rata nilai kelas eksperimen 25,15 dan nilai rata-rata kelas kontrol 15,52 hal ini dapat dilihat pada pola jawaban siswa pada soal nomor 1, seperti jawaban siswa dengan kode S15 mengungkapkan larutan tersebut termasuk larutan penyangga, jawaban yang 
berbeda juga diperoleh pada siswa dengan kode S21 mengungkapkan data yang diperoleh dari percobaan pada larutan $\mathrm{Q}$ dan $\mathrm{S}$ termasuk larutan penyangga karena mampu mempertahankan $\mathrm{pH}$ ketika ditambahkan sedikit asam atau ditambahkan sedikit basa atau diencerkan, jawaban yang berbeda juga diperoleh pada siswa dengan kode S9 mengungkapkan $\mathrm{pH}$ pada larutan ini berbeda dengan larutan lainnya, jawaban yang berbeda juga diperoleh pada siswa dengan kode S11 mengungkapkan untuk menentukan larutan penyangga asam tidak boleh terlalu kurang dari $\mathrm{pH}$ awal dan basa tidak boleh terlalu lebih dari pH awal, hal ini menunjukan bahwa dari hasil pretest yang dilakukan siswa masih kurang dalam memahami suatu konsep dapat dilihat dari beberapa variasi jawaban siswa dan banyak siswa yang mengalami kesulitan dalam memahami materi larutan penyangga.

Kemudian setelah mendapatkan data hasil pretest diuji normalitas untuk kelas eksperimen dan kelas kontrol bedasarkan hasil perhitungan dengan excel menggunakan chi kuadrat dari hasil kelas eksperimen dan kelas kontrol $X_{\text {hitung }}{ }^{2}$ kurang dari $\mathrm{X}_{\text {tabel }}{ }^{2}$ sehingga dapat disimpulkan bahwa data sampel berasal dari poulasi berdistribusi normal.

Uji homogenitas dua varians antara kelas eksperimen dan kelas kontrol dari hasil pretest diperoleh nilai signifikasi sebesar 0,197 dan untuk hasil posttest kelas eksperimen dan kelas kontrol 0,061. Jika nilai probability >0,05 maka data bersal dari varians yang sama atau kedua kelas homogen.

Data hasil posttest pada materi larutan penyangga yang ditunjukan pada tabel 4.4. dengan rata-rata nilai kelas eksperimen 71,85 dan nilai kelas kontrol 62,76. Hal ini menunjukan kelas eksperiman yang menerapkan model pembelajaran PBL untuk meningkatkan keterampilan berpikir kritis dan pemahaman konsep pada materi larutan penyangga masuk dalam kategori cukup.

Setelah mengetahui hasil pretest dan hasil posttest kemudian akan diuji N-Gain untuk mengetahui peningkatan 
keterampilan berpikir kritis dan pemahaman konsep pada kelas eksperimen. Berdasarkan hasil perhitungan uji $\mathrm{N}$-Gain score untuk kelas eksperimen (model pembelajaran $\mathrm{PBL}$ ) sebesar 63,30 termasuk dalam kategori cukup evektif dengan nilai $\mathrm{N}$ Gain score minimal $20 \%$ dan maksimal $70 \%$. Hasil N-Gain skor untuk kelas kontrol (metode konvesional) sebesar 56,50 termasuk dalam kategori cukup efektif dengan nilai $\mathrm{N}$-Gain score minimal $20 \%$ dan maksmal $70 \%$.

Penelitian ini membuktikan bahwa pembelajaran melalui model PBLdapat digunakan sebagai salah satu metode untuk meningkatkan keterampilan berpikir kritis dan pemahaman konsep siswa terhadap materi larutan penyangga. Model pembelajaran PBLdapat dirancang sebagai kegiatan penemuan yang dapat membantu siswa untuk meningkatkan keterampilan berpikir kritis dan pemahaman konsep.

\section{KESIMPULAN}

Berdasarkan hasil penelitian yang telah dibahas sebelumnya, diperoleh kesimpulan mengenai pengaruh penerapan model pembelajaran PBLterhadap peningkatan keterampilan berpikir kritis dan pemahaman konsep siswa pada materi larutan penyangga, bahwa terdapat pengaruh penerapan model pembelajaran PBL terhadap peningkatan keterampilan berpikir kritis dan pemahaman konsep siswa pada materi larutan penyangga.

Hal ini ditunjukan oleh analisa uji perbedaan rata-rata hasil posttest kelas eksperimen menunjukan hasil yang lebih baik dibandingkan kelas kontrol. Kelas eksperimen memperoleh ratarata nilai posttest 72,08 sedangkan nilai kelas kontrol 65,48. Uji normalitas Gain pada hasil belajar kognitif siswa menunjukan bahwa kelas eksperimen mengalami peningkatan lebih baik dalam keterampilan berpikir kritis dan pemahaman konsep sebesar 63,297 dan kelas kontrol peningkatannya sebesar 56,50 dengan kriteria sedang. 


\section{DAFTAR PUSTAKA}

Facione, N. C. \& Facione, P. A. (2008). Crtical Thingking and Clinical Judgment. From Critical Thingking and Clinical Reasoning in the Health Sciences: A Teaching Anthology. Insight Assessment/ The California Academic Press: Millbrae CA

Haryani, D. (2012) Membentuk Siswa Berpikir Kritis Melalui Pembelajaran Matematika. Seminar Nasional Matematika dan Pendidikan Matematika FMIPA UNY. 165-174.

Lidinillah, D. A. M. (2014). Pembelajaran Berbasis Masalah (Problem Based Learning). Jurnal penelitian, Vol. 3. 2-8.

Sugiyono. (2009). Metode Penelitian Pendidikan. Bandung: Alfabeta

Widowati, A. (2009). Pengembangan Critical Thinking Melalui Penerapan Model PBL (Problem Based Learning) dalam Pembelajaran Sains. Prosiding Seminar Nasional Penelitian, Pendidikan, dan Penerapan MIPA. 84-89.

Wijaya, E. Y., Sudjimat, D. A., \& Nyoto, A. (2016). Transformasi Pendidikan Abad 21 Sebagai Tuntutan Pengembangan Sumber Daya Manusia Di Era Globa. Prosiding Seminar Nasional Pendidikan Matematika. 1(1). 263-278.

Wulandari, W. Liliasari, F.M., Supriyanti, T. (2011). Problem Based Learning Untuk Meningkatkan Keterampilan Berpikir Kreatif Dan Penguasaan Konsep Siswa Pada Materi Larutan Penyangga. Jurnal Pengajaran MIPA. 16(2).

Zubaidah, S. (2010, Januari). Berpikir Kritis: Kemampuan Berpikir Tingkat Tinggi yang Dapat Dikembangkan Melalui Pembelajaran Sains. Seminar Nasional Sains: Optimalisasi Sains untuk Memberdayakan Manusia. 1-14. 